\title{
Evidence of the Organization of Physical Activity and Health Programs in the Workplace on Depression and Anxiety: a Mini Review on the Spanish Case
}

\author{
Víctor Jiménez Díaz Benito* \\ Faculty of Health, Camilo José Cela University, Castillo de Alarcón, Madrid, Spain \\ *Corresponding author: Víctor Jiménez Díaz Benito, Faculty of Health, Camilo José Cela University, Castillo de Alarcón, \\ Madrid, Spain
}

\section{ARTICLE INFO}

Received: 蔧 July 10, 2021

Published: 幽 July 27, 2021

\section{ABSTRACT}

Citation: I-Shuo Huang. Marine Algal Bioactive Metabolites: Effects and Occurrence. Biomed J Sci \& Tech Res 37(3)-2021. BJSTR. MS.ID.006010.

\begin{abstract}
Mini Review
Stress and anxiety are closely related to lifestyle and have been an important focus of scientific interest collected in the literature since the early 1950s [1]. In turn, anxiety and depression are two indissoluble concepts in today's work society. On the one hand, anxiety can become a clinical object whose general symptoms can be stopped with timely treatment; however, prevention and lifestyle have been shaping the appropriate action plan to avoid depression: a psychiatric illness whose situation Clinic is different from anxiety and can be alarming for patients and their environments [2]. The purpose of this mini review is to review the state of the art on the influence of physical activity programs at work on mental health and to briefly discuss the methodological processes that prevent their adequate functionality in Spanish companies. To do this, it is initially advisable to dwell on the implications of its global impact. The concentration of mental disorders is an important public health problem that has a significant impact on health spending beyond the mere influence on the physical and mental health of the people who suffer from it. However, depressive disorders can be related not only to anxiety, but to other physical pathologies [2-4]. Various researchers have pointed to the circumstances motivated by the way of life as the main intervening agents. One of them is the Polish philosopher Zygmunt Bauman, responsible for some thirty articles and references related to "liquid modernity".
\end{abstract}

According to Bauman, today time obeys continuous ruptures and discontinuities, that is, if time was linear before, today there are intervals that separate the successive blocks and establish the links between them than by the specific content of the blocks themselves [5]. The pointillist times that today are moving away from the linear world have only increased the symptoms associated with people's physical and mental health [5]. The consequences on mental health inherent to the difficulties of our contemporary society, the permanent linear ruptures and the way of life have shown the enormous incidence of depression over chronic diseases since the beginning of the century [6]. However, it is generally urban centers that suffer the consequences of depressive disorders in the workingage population. In this direction, the work of Ayuso Mateos, et al. [6] found a higher prevalence of depression in urban centers compared to rural ones in three out of every four European countries analyzed. Despite the limitations indicated in their research, according to which they could not analyze all European countries, their pioneering contributions made it possible to understand the concentration of mental disorders associated with the workplace. Business organizations are concentrated in population centers according to which there is a greater concentration of resources for the exploitation of business models $[7,8]$. 
Given the important impact that the workplace has on a social model based on the forces of work, previous research refers to the strategic importance of influencing preventive work on the population employed in their workplace [9-12]. In this sense, it is important to target the jobs where the highest incidence of mental illness is concentrated [13,14]. Since the beginning of the sixties, health development, to put a greater emphasis on preventive matters, has taken on a greater role in the prevention plans of different business organizations [15-17]. Similarly, many companies try to focus on the well-being of their employees in order to favor the best conditions for maximum performance and productivity in accordance with the financial objectives of the companies [18-22]. The binomial work and self-realization are closely related [23]. Given the rhythm of life associated with contemporary society, welfare policies in companies have been a reality for years. Given the limited evolution of Spanish labor legislation, there are marked segments of the population that can hardly reconcile their working life with their family life, bringing with it not only a reduction in the practice of physical activity, but also an important limitation towards incardination of his free time [16,24-26]. As the so-called time policies have not satisfied the elimination of social barriers, anxiety and, therefore, depression, have been shown in their relationship with people's habits [27]. The scientific literature alludes to the importance of social barriers to the practice of physical activity $[28,29]$.

If people cannot practice and work or professional occupations cause them stress, anxiety and even depression, it seems appropriate to refer to the workplace as the central unit of interventions to wield effects on people and business organizations. Likewise, the removal of barriers denotes not only an action of clinical intervention, butit is also a framework of action of an organizational nature, the planning of which must be duly designed according to the existing theory [30]. In this sense, in the same way that people with depressive disorders and the health professionals who care for them face the social barriers that affect them, we plan the hypothesis that their coadjutant demands to the usual treatments can be attended if the plan action includes the appropriate organizational mechanisms to improve the habits of patients. As time policies do not seem to settle in our society, it seems appropriate that, for the time being, efforts should be concentrated towards prevention through the workplace to counteract the symptoms, improve the quality of life and, ultimately, reduce the incidence of depressive disorders on health and the health system. It is precisely this thesis that supports the objective of directing preventive action to work centers, despite the social and organizational barriers empirically collected in previous studies [25,26,31]. Fortunately, physical activity has been shown as a fundamental actor towards the improvement of the symptoms of patients, however, it should be noted, as Ströhle
(2009) did, the importance of addressing the methodological rigor of the interventions, whose intention is to offer Adjuvant clinical treatments to conventional ones need to be aligned with sufficient scientific rigor. As an example, greater effects on anxiety have been found in those studies that randomized the subjects, although the programs had to last longer than ten weeks to improve state-trait anxiety. The duration of the exercise seems to be decisive, however, the characteristics and, more specifically, the duration of the ideal intervention programs to reduce the state and the trait are still unknown [32]. For its part, chronic stress can be related to lack of physical activity [33]. Numerous multi-component programs have also appeared on stress and anxiety $[15,34,35]$, however, the effects and characteristics of the interventions analyzed have been highly variable and multi-component programs have had a notable impact [16].

Furthermore, the methodological quality found in the studies does not appear to be conclusive about appropriate intervention programs [36]. It is for this reason that it is necessary to carry out new interventions that determine, based on previously located scientific literature, the type and appropriate characteristics of the interventions that attempt to achieve a significant improvement in the measures associated with depression and anxiety. Physical exercise can be an attractive factor, but, given the scarcity of studies that propose the treatment of this variable in Spain, it seems necessary, at least, to raise the need to continue carrying out new studies that provide more scientific evidence, in continuation with previous studies carried out in Spain [16,37-39], eliminating the existing heterogeneity and increasing the methodological quality of the studies.

\section{References}

1. Selye H (1956) The stress of life. Nueva York: McGraw-Hill.

2. Cardila F, Martínez ÁM, Martín ABB, Del Carmen Pérez Fuentes M, Jurado MdMM, et al. (2015) Prevalencia de la depresión en España: Análisis de los últimos 15 años. European Journal of Investigation in Health. Psychology and Education 5(2): 267-279.

3. Reme SE, Tangen T, Moe T, Eriksen HR (2011) Prevalence of psychiatric disorders in sick listed chronic low back pain patients. European Journal of Pain 15(10): 1075-1080.

4. Patten SB, Williams JV, Wang J (2006) Mental disorders in a population sample with musculoskeletal disorders. BMC Musculoskeletal Disorders $7(1): 37$.

5. Bauman Z (2015) Modernidad líquida. Madrid: Fondo de cultura económica.

6. Ayuso Mateos JL, Vázquez Barquero JL, Dowrick C, Lehtinen V, Dalgard OS, et al. (2001) Depressive disorders in Europe: prevalence figures from the ODIN study. The British Journal of Psychiatry 179(4): 308-316.

7. Blanch J (2003) Trabajar en la modernidad industrial. In: (Coord) Blanch J (Edt.)., Teoría de las relaciones laborales: fundamentos, Editorial UOC ed, Barcelona, pp. 19-148.

8. Brown W, Bryson A, Forth J, Whitfield K (2009) The evolution of the modern workplace. Cambridge: Cambridge University Press. 
9. Benda F (2019) Structural predictors of adherence to physical activity at the workplace: A systematic overview. Bewegungstherapie Gesundheitssport 35(3): 127-133.

10. Crews DJ, Landers DM (1987) A meta-analytic review of aerobic fitness and reactivity to psychosocial stressors. Medicine \& Science in Sports \& Exercise 19(5): 114-120.

11. Kuijpers W, Groen WG, Aaronson NK, Van Harten WH (2013) A systematic review of web-based interventions for patient empowerment and physical activity in chronic diseases: relevance for cancer survivors Journal of medical Internet research 15(2): e37.

12. Proper KI, Singh AS, Van Mechelen W, Chinapaw MJ (2011) Sedentary behaviors and health outcomes among adults: a systematic review of prospective studies. American Journal of Preventive Medicine 40(2): 174-182.

13. Bauer UE, Briss PA, Goodman RA, Bowman BA (2014) Prevention of chronic disease in the $21^{\text {st }}$ century: elimination of the leading preventable causes of premature death and disability in the USA. The Lancet 384(9937): 45-52.

14. González K, Fuentes J, Márquez JL (2017) Physical Inactivity, Sedentary Behavior and Chronic Diseases. Korean Journal of Family Medicine 38(3): 111-115.

15. Durán MM (2010) Bienestar psicológico: el estrés y la calidad de vida en el contexto laboral. Revista nacional de administración 1(1): 71-84.

16. Jiménez V (2019) Una visión organizativa de los programas de promoción de la salud en las empresas europeas: la influencia de la actividad física y razones de aplicación a la prostatitis crónica. Facultad de Ciencias de la Actividad Física y del Deporte (INEF) (UPM): Universidad Politécnica de Madrid.

17. Lemon SC, Zapka J, Li W, Estabrook B, Magner R, et al. (2009) Perceptions of worksite support and employee obesity, activity, and diet. American Journal of Health Behavior 33(3): 299-308.

18. Cox M, Shephard RJ, Corey P (1981) Influence of an employee fitness programme upon fitness, productivity and absenteeism. Ergonomics 24(10): 795-806

19. Haskell WL (1989) Exercise as a means of maximizing human physical performance and productivity. Biological effects of physical activity, pp. 115-126.

20. Shephard RJ (1995) Worksite Health Promotion and Productivity. In Kaman RL (Edt.)., Worksite health promotion economics: Consensus and analysis: Human Kinetics Publishers, p. 1-19.

21. Van der Voordt TJM (2004) Productivity and employee satisfaction in flexible workplaces. Journal of Corporate Real Estate 6(2): 133-148.

22. Bertera RL (1990) The effects of workplace health promotion on absenteeism and employment costs in a large industrial population. American Journal of Public Health 80(9): 1101-1115.

23. Noguera JA (2000) El problema de la definición del trabajo. Ponencia presentada en los I Encuentros entre Humanidades y Ciencias Sociales, Barcelona IUC, UPF

24. Martínez del Castillo J, Jiménez Beatty JE, Campos Izquierdo A, Del Hierro D, Martin Rodriguez M, et al. (2007) Barreras organizativas y sociales para la práctica de actividad física en la vejez. European Journal of Human Movement 19: 13-35.
25. Martínez del Castillo J, Martin Rodriguez M, Del Hierro D, Jiménez Beatty JE, González Rivera (2008) Barreras a la actividad física en las mujeres adultas y alternativas de conciliación. Actividad Física y Deporte: Ciencia y profesión 9: 12-24.

26. Martínez del Castillo J, Moscoso Sánchez D, Martín Rodriguez M, Jiménez Beatty J, Del Hierro D (2016) Cambios sociales y cambios en las prácticas y demandas de actividad física y deporte: 1966-2016. Nuevos retos organizativos. In: Martínez del Castillo J, Moscoso Sánchez D, Martín Rodriguez M, Jiménez Beatty J, Del Hierro D (Eds.)., INEF 50 Años. Madrid: INEF, pp. 83-117.

27. Costa M, López E (2009) Educación para la salud: Una estrategia para cambiar los estilos de vida. Revista educación en valores 12: 86-103.

28. Schmier JK, Jones ML, Halpern MT (2006) Cost of obesity in the workplace. Scand J Work Environ Health 32(1): 5-11.

29. Hutchinson AD, Wilson C (2012) Improving nutrition and physical activity in the workplace: a meta-analysis of intervention studies. Health Promotion International 27(2): 238-249.

30. Fertman CI (2015) Workplace health promotion programs: planning, implementation, and evaluation. San Francisco: Jossey-Bass: John Wiley \& Sons.

31. Martínez del Castillo J, Jiménez Beatty J, Campos Izquierdo A, Del Hierro D, Martín M, et al. (2007) Barreras organizativas y sociales para la práctica de actividad física en la vejez. European Journal of Human Movement 19:13-35.

32. Petruzzello SJ, Landers DM, Hatfield BD, Kubitz KA, Salazar W (1991) A Meta-Analysis on the Anxiety-Reducing Effects of Acute and Chronic Exercise. Sports Med 11(3): 143-182.

33. Kouvonen A, Vahtera J, Oksanen T, Pentti J, Väänänen AK, et al. (2012) Chronic workplace stress and insufficient physical activity: a cohort study. Occupational and Environmental Medicine 70(1): 3-8.

34. Altchiler L, Motta R (1994) Effects of aerobic and nonaerobic exercise on anxiety, absenteeism, and job satisfaction. Journal of Clinical Psychology 50(6): 829-840

35. Beehr TA, Newman JE (1978) Job stress, employee health, and organizational effectiveness: A facet analysis, model, and literature review 1. Personnel psychology 31(4): 665-699.

36. Furlan A, Gnam W, Carnide N, Irvin E, Amick B, et al. (2012) Systematic Review of Intervention Practices for Depression in the Workplace. Journal of Occupational Rehabilitation 22(3): 312-321.

37. Jiménez V, Barriopedro M, Martínez del Castillo J (2014) Intervenciones de actividad física en el lugar de trabajo: una revisión de los estudios europeos. In: Jiménez V, Barriopedro M, Martínez del Castillo J (Eds.)., VIII Congreso Internacional de la Asociación Española de Ciencias del Deporte; Cáceres, Extremadura: Asociación Española de Ciencias del Deporte.

38. Puig Ribera A, Bort Roig J, Gine Garriga M, Gonzalez Suarez AM, Martinez Lemos I, et al. (2017) Impact of a workplace 'sit less, move more' program on efficiency-related outcomes of office employees. BMC Public Health 17(1): 455.

39. Puig Ribera A, McKenna J, Gilson N, Brown WJ (2008) Change in work day step counts, wellbeing and job performance in Catalan university employees: a randomised controlled trial. Promotion and Education 15(4): 11-16 
ISSN: 2574-1241

DOI: 10.26717/BJSTR.2021.37.006010

Víctor Jiménez Díaz Benito. Biomed J Sci \& Tech Res

(C) This work is licensed under Creative

BY Commons Attribution 4.0 License

Submission Link: https://biomedres.us/submit-manuscript.php

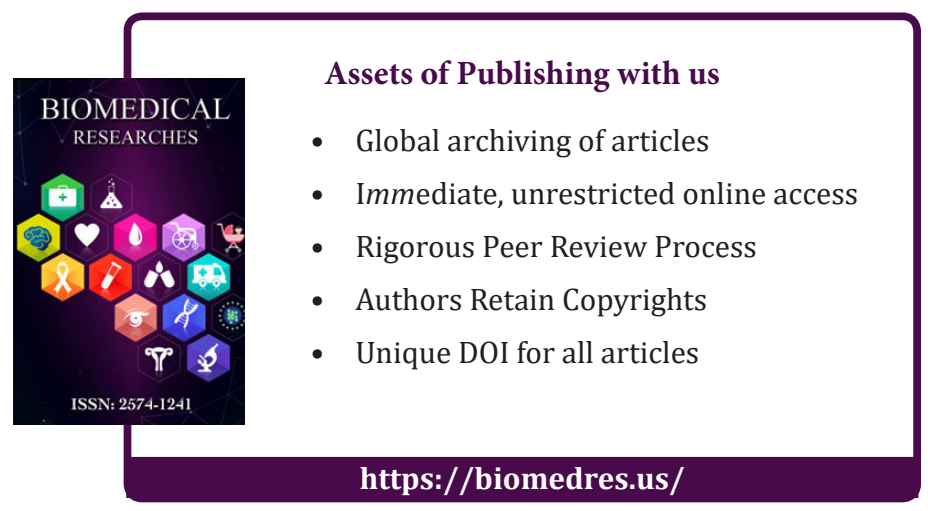

